Agricultural

Marketing

Service

March 2016

\title{
Impacts of Intramodal Competition on 2012 Railroad Rates for Wheat (Summary)
}

Peter Caffarelli and Jesse Gastelle

This is a summary of "Impacts of Intramodal Competition on 2012 Railroad Rates for Wheat" by Michael W. Babcock, Department of Economics, College of Arts and Sciences, Kansas State University. This paper was developed with funding from the Agricultural Marketing Service (AMS) through cooperative agreement number 14-TMXXX-KS-0026. The full paper is available at http://www.k-state.edu/economics/staff/websites/babcock/ Intramodal\%20Railroad\%20Competition\%20Impacts\%20on\%20Railroad\%20Wheat\%20Rates\%2010-2015.pdf.

\section{What is the Issue?}

This research investigates the pricing behavior of railroads for wheat shipments by exploring the relationship between intra-State railroad competition and railroad rates for wheat in the largest wheat-producing States (Idaho, Kansas, Minnesota, Montana, North Dakota, Oklahoma, South Dakota, Texas, and Washington). The objectives of the research are to: (1) measure the impact of the intensity of intra-State railroad competition on railroad wheat rates; (2) model the impacts of railroad costs, intra-State railroad competition, and intermodal competition on rail wheat rates; (3) identify and measure the major cost determinants of railroad wheat rates; and (4) examine the hypothesis that railroad intramodal competition varies within a State with implications for intra-State variation in railroad wheat rates.

\section{How Was the Study Conducted?}

The study used ordinary least squares (OLS) regression analysis to estimate the following model in double-log specificationi utilizing the 2012 Surface Transportation Board (STB) Confidential Waybill sample and other data:

Where:

$$
\text { RATE = b0 + b1 CARWT + b2 TSW + b3 DIST + b4 BARGE + b5 HHI + e1 }
$$

RATE: $\quad$ Rail revenue per ton mile

CARWT: Weight of each loaded hopper car

TSW: $\quad$ Total shipment weight

DIST: Distance in rail miles between origins and destinations

BARGE: $\quad$ Distance from origin to nearest barge loading location

HHI: Herfindahl-Hirshman Indexii 
In principle, longer distances and larger trains should be lower cost per ton-mile, because fixed costs are spread over more ton-miles. As expected, the distance in rail miles from origin to destination (DIST) and the total shipment weight (TSW) each had a negative correlation with railroad rates and were significant at the 1-percent level.iii Economic theory predicts that as the costs of alternatives to rail transportation rise (or fall), the price of rail should rise (or fall). The distance from origin to nearest barge loading location (BARGE) had the expected positive correlation and was significant at the 1-percent level. The weight of each individual covered hopper car (CARWT) was not significantly related to RATE. This result is somewhat surprising because car weight should be similar to distance and train weight in that higher weights should lower per ton-mile rates, as they spread out the fixed costs. The test outcome is possibly the result of a data problem, because car weight only takes on two values and may not have given the model enough variation to make an accurate estimate. The Herfindahl-Hirschman Index (HHI) was also not significantly related to wheat rates.

This result is unexpected because, in theory, additional railroads should compete with each other by lowering prices to attract customers.

The degree of railroad competition varies by State. Previous research has found that the presence of two railroads of roughly equal size in a grain transportation market results in lower rail rates. Based on the number of wheat shipments from the Crop Reporting Districts (CRDs) served by one class railroad, Idaho and North Dakota have the most "single carrier" shipments, while Kansas, Minnesota, and Texas have the fewest. Idaho has no CRDs served by at least two Class I railroads while all seven of the Kansas CRDs are served by at least two Class I railroads. For wheat, 35 CRDs (61 percent of the total CRDs) are served by at least 2 Class I railroads. Moreover, substantial variation in HHIs within seven of the nine States reflects variation in railroad competition within States.

When comparing the high and low HHI of CRDs in each State, the study found that Idaho has no variation, and Washington's high and low HHI only differed by 6 percent. Conversely, the other States have very large percentage differences in $\mathrm{HHI}$ ranging from 88 percent (Oklahoma) to 212 percent (Minnesota). Thus, intramodal competition within States appears to be present in most cases. The absence of the expected significant relationship between railroad competition and wheat rates is possibly the result of anomalies in the 2012 data. This could be the impetus for further research using a multi-year panel dataset.

Overall, the study found that railroad cost factors (shipment distance and total shipment weight) and intermodal competition are important determinants of railroad wheat tariff rates.

\section{Preferred citation:}

Caffarelli, Peter and Gastelle, Jesse, Impacts of Intramodal Competition on 2012

Railroad Rates for Wheat (Summary), U.S. Department of Agriculture, Agricultural Marketing Service, March 2016. Web $\leq$ http://dx.doi.org/10.9752/TS215.03-2016>

Photo credit: CKevin Cavanaugh

\footnotetext{
i Ordinary least squares regression analysis is a method of estimating the relationship between two variables, while holding other important variables constant. The double-log specification provides a better fit to non-linear relationships, and transforms the interpretation of the coefficients into percentages.

ii The Herfindahl-Hirschman Index ( $\mathrm{HHI}$ ) is a widely used measure of competition. In general, it is defined as the sum of the squares of the market shares of firms in an industry. Here it measures the market shares of railroads in a crop reporting district. It can be unintuitive because a large $\mathrm{HHI}$ implies few firms are in the industry. A small $\mathrm{HHI}$ implies many firms are in the industry.

iii In statistical analysis, hypothesis tests are used to test the validity of a claim. The hypothesis in question is called the null hypothesis. In this case, the null hypothesis being tested is that the coefficient on DIST is equal to zero (i.e. DIST has no significant impact on RATE). Economists generally accept that a test outcome below the 5 percent level indicates strong (significant) evidence against the null hypothesis and suggests that there is a relationship between DIST and RATE.
} 